Jurnal Minds: Manajemen Ide dan Inspirasi

Vol. 7 Number. 2, (December) 2020: 65-78

\title{
ENHANCING THE LITERACY OF SHARIA FINANCIAL TECHNOLOGY FOR THE GENERATION X, Y AND Z IN INDONESIA
}

\author{
Ika Yunia Fauzia* \\ STIE Perbanas Surabaya, Indonesia
}

\begin{abstract}
This research tries to improve financial literacy through sharia fintech, especially in payment gateway, peer to peer lending, and crowdfunding. It focuses mainly on how the $X, Y$, and $Z$ generations may improve financial literacy. The research uses a qualitative approach in analyzing its case study, involving 30 informants in Indonesia who have the knowledge or other ways and access sharia fintech. The research will then select 30 informants and ten people to represent each $X, Y$, and $Z$ generations. The research shows that $X$ generations are more literate in sharia fintech than $Y$ and $Z$ generations to disseminate and spread sharia fintech and improve its infrastructures and services in its products.
\end{abstract}

Keywords: Financial literacy, sharia fintech, X, Y, and Z generations

Submitted: 12 September 2020; Revised: 10 October 2020; Accepted: 2 November 2020

*Corresponding author: Ika.yunia@perbanas.ac.id

DOI: $10.24252 /$ minds.v7i2.15871

ISSN-E: 2597-6990

ISSN-P: 2442-4951 


\section{INTRODUCTION}

Financial literacy explains how a person thinks about his financial condition to manage his finances to a better stage (Handida \& Sholeh, 2018). Financial literacy is also defined as a series of processes and activities to increase the knowledge, confidence, and skills of consumers and the broader community to manage finances better (OJK, 2014 in ojk.go.id, accessed 06/07) / 2020). Financial Service Authority (OJK), in the blueprint of the Indonesian Financial Literacy National Strategy, has set the vision, mission, and principles in financial literacy, with the vision of "realizing an Indonesian society that has a high level of financial literacy (well literate), so that people can choose and use finance to improve welfare." The mission of the SNLIK perspective literacy is "first, to carry out education in the field of finance to the people of Indonesia so that they can manage their finances intelligently; second, to increase access to information and use of financial products and services through the development of infrastructure that supports financial literacy. "

The emergence of several fintech-based business startups in Indonesia has changed the way people look at behavior related to their financial activities. For example, for some matters relating to the banking world, people need banking services replaced by Fintech rather than the banks themselves. The public also likes cashless by minimizing cash because they prefer to transact with fintech gateway services. Therefore, Fintech confirms that there is a shift from face-toface business to platform-based business.

The high use of Fintech, along with fintech-based fraud complaints, explains that there is limited literacy from the public about the existence of Fintech itself. Fintech, which also targets non-bankable segmentation of the community, has limited the public's knowledge of it. The public only follows trends in the use of Fintech without understanding well the development process is related to regulations, rules, and things related to it. Also, regarding sharia fintech, there is an even lower understanding of the form, operation, and face. Whereas people of adult age, commonly referred to as Gen X, consist of the most professional figures due to career maturity, finance, and age. The next generation is Gen $Y$ and $Z$, who is supposed to be the most aware gene of technology, and when most of $\mathrm{Y}$ and $\mathrm{Z}$ genes cannot use technology proportionally, the incredible power of this generation will be wasted (Fauzia, 2019). This gene should become productive economic and business actors, especially those related to Islamic Fintech.

This research is expected to answer the gap between the development of financial-based technology and the reality of the community's low interest in using Fintech. Indonesian people's knowledge of Fintech is low, especially related to Islamic Fintech. This condition makes the penetration of Islamic Fintech is prolonged. Sharia Fintech must also always comply with the rules of the Fatwa of the National Sharia Council-Indonesian Ulema Council (DSN-MUI), No. 117/DSN-MUI/II/2018 concerning "Information Technology-Based Financing Services Based on Sharia Principles. The fundamental difference between sharia fintech and conventional is the absence of interest that contains 
usury elements in sharia fintech, some financing in sharia fintech is performed by murabahah, ijarah wa al-iqtina, musharakah, etc. Therefore, the discussion about how literacy improvement is related to Islamic financial technology for X Y Z genes becomes a niche topic to be investigated in the discussion of sharia fintech.

\section{THEORETICAL REVIEW}

\section{Digital-Based Financial Literacy}

Financial literacy means the level of attitude-behavior and knowledge that an individual has regarding financial products and services and talks about how right an individual is at personal finance (Tony \& Desai, 2020). Financial literacy can be generally defined as a person's ability to understand, analyze, manage, and communicate personal finance matters. More specifically, it refers to the set of skills and knowledge that allows an individual to make informed and effective decisions through their understanding of finances. It is the ability to make informed judgments and make effective decisions regarding the use and management of money (Prasad \& Meghwal, 2017).

The Financial Services Authority (OJK) explains that financial literacy is knowledge, skills, and beliefs that influence attitudes and behaviors to improve the quality of decision making and financial management in order to prosper (OJK, 2019). According to Paul Gilster, in his book Digital Literacy (1997) as cited in KemDikBud (2017), digital literacy is defined as the ability to understand and use information in various forms from a wide variety of sources that are accessed through computer devices. Bawden (2001)) offers a new understanding of digital literacy that is rooted in computer literacy and information literacy. Computer literacy developed in the 1980s, when microcomputers were increasingly used, not only in the business environment but also in society. However, new information literacy became widespread in the 1990s as information became more easily compiled, accessed, disseminated through networked information technology. Thus, referring to Bawden's opinion, digital literacy is more associated with technical skills of accessing, compiling, understanding and disseminating information.

OJK (2017), in the Indonesian Financial Literacy National Strategy, explains that Indonesia's financial literacy intends to move towards a well literate and financial inclusion in Indonesian society. Financial literacy is useful for enhancing the ability to manage public finances. Financial literacy is also essential in order to increase financial access for Indonesian people in order to realize well being. Through the National Council for Inclusive Finance (DNKI), the government has discussed and established six focus financial inclusion activities in Indonesia in 2019. The six focuses are, first, increasing financial literacy and consumer protection; second, the expansion of account opening; third, the acceleration of certification of community property rights that can be used as collateral; fourth, optimization in bank agent services; fifth, improving digital financial services and non-cash transactions, as well as; sixth, strengthening financial inclusion monitoring and evaluation (Kominfo, 2019). 


\section{Sharia Financial Technology}

Financial technology is an innovation in technology-based finance. Transactions in Fintech include payment gateways, peer to peer lending, personal financial management, or crowdfunding (Fianto, Hendratmi \& Aziz, 2020). Siregar (2016) states that digital-based financial services are currently developing in Indonesia, namely payment channel systems, digital banking, online digital insurance, peer to peer lending, and crowdfunding. Romanova and Kudinska (2016) explain that Fintech is a software-based business and modern technology that provides financial services. The competitive advantage of Fintech is that financial services are highly standardized and low-cost, internet-based, and less geographically concentrated. Lee and Shin (2018) explain that Fintech promises a new ecosystem for the financial industry at a relatively low cost by improving the quality of financial services and creating a more diverse and stable financial landscape. Firmansyah \& Ramdani (2018) explain that the Islamic FinTech startup plays an essential role in fostering financial inclusion and decreasing social problems in Indonesia by developing new technology and a new business model.

The five elements in the fintech ecosystem, according to (Ryandono, 2018) are first, Fintech for startups (payments, loans, crowdfunding, capital markets, and insurance companies); second, technology developers (e.g., big data analysis, cloud computing, cryptocurrency, and social media developers; third, government (e.g., financial regulators and legislative bodies); fourth, financial customers (e.g., individuals and organizations), and; fifth, traditional financial institutions (e.g., traditional banks, insurance companies, stockbrokers and venture capital) Bank Indonesia Regulation Number 19/12/PBI/2017 concerning Financial Technology Implementation can carry out financial activities in the form of: first, payment systems; second, market support; third, investment management and risk management, fourth, loans, financing and capital supply, fifth, other financial services.

Er and Mutlu (2017) examined the "Financial Inclusion and Islamic Finance: A Survey of Islamic Financial Literacy Index." It begins with World Bank data, stating that financial exclusion on religious grounds is $7 \%$ globally. $9.7 \%$ of this amount is in the D-8 country group. Group D-8 is a developing country declared as "Developing 8 Countries", having a majority Muslim population who want to cooperate reasonably with one another in development. The eight countries are Bangladesh, Indonesia, Iran, Malaysia, Nigeria, Pakistan, and Turkey. In Turkey, Islamic Banks are the ones who benefit from a person's religious sensitivity. So the knowledge of Islamic financial literacy is fundamental to increase financial inclusion. Setyowati, Harmadi, and Sunarjanto (2018) also examined the "Islamic Financial Literacy and Personal Financial Planning: A-Socio-Demographic Study," which aims to measure the level of Islamic Financial Literacy (IFL) in Solo and examine the effect of IFL on personal financial planning. Socio-demographic variables such as age, gender, marital status, education level, and income are used as control variables. The study was conducted through surveys and Ordinary Least Square (OLS), using purposive sampling methods and limiting respondents' education and income levels. The results showed that: (1) the IFL 
rate in Solo was $64.66 \%$; (2) people with acceptable IFL levels will be better at managing their finances; (3) people with an adequate level of IFL would prefer to invest in Islamic assets.

Rusydiana (2018), in her research "Developing Islamic Financial Technology In Indonesia," states that the financial technology market in Indonesia looks bright, but its utilization is still low. Even though Indonesia is a country with the largest Muslim population globally, this study attempts to address several issues related to financial technology related to necessary foundations, critical ecosystems, or stakeholders involved in developing Islamic Fintech in Indonesia. This study uses an interpretative structural model (ISM) approach. Some of the problems that have hampered the Islamic fintech industry's development are (a) the lack of policy instruments that support Fintech; (b) the availability of human resources to develop Fintech. The strategy for developing Fintech is analyzing data in big data and human resources in digital marketing. Ecosystems or actors involved in fintech development are also needed, namely the government/regulator, educational institutions/universities, industry/banks, and financial institutions. Abdullah and Chong (2014) supported several parties' role to make Islamic financial products accepted by investors on a broader scale. The purpose of this study is to determine the factors that influence society, related to their literacy views on Islamic financial products and services. This has implications for recommendations to Islamic financial products and services related to public literacy knowledge about these products and services.

\section{Generation X, Y, Z, and Financial Technology}

Gen X are born between 1965-1980, Gen Y or millennials are born between 19801994, and Gen Z is born between 1996-2015. Each generation has its characteristics. Past generations are more likely to be challenging to adapt to technological advancements. Unlike the current young generation commonly identified with the $Y$ generation or millennial generation, they must follow the changing technological progress trends. The emergence of gadgets or smartphones and the rapid development of internet technology have brought significant changes to most humans and marked the birth of generations $Y$ and Z (Fauzia, 2019).

There are various kinds of human characters according to the differences in each generation. Generational differences in a marketing environment affect the behavior of each in a transaction. This fact gave rise to various new approaches in developing sales management and marketing management. The difference between one generation and another arises because of researchers' classifications, says Manheim (1952). In his sociological studies, there is a gap between the older generation's values and the reality faced and desired by the younger generation. Young and old have the same life span as one another, so they experience the same experiences and life events. Putra (2016) explains that some sociologists classify several generations between human life spans and other generations. These differences are significant to study because they relate to daily behavior, 
including those related to transaction behavior and internet media usage behavior.

The development of fintech and generation $X, Y, Z$ begins with the background of fintech development years from fintech 1.0, 2.0, 3.0 to 3.5. Fintech is fintech 1.0 (1966-1987) still straightforward, then continued with fintech 2.0 (1987-2008), realized in e-banking services. Fintech 3.0-3.5 is a form of the fintech era from 2008 until now. The link between generation X, Y, and Z with Fintech must also be continuously connected with external factors, for example, information technology factors due to uneven internet penetration from one place to another (Ministry of Communication and Information, 2018). Therefore, this research is limited to the Surabaya area, with better internet access than other areas for Gen $X, Y$, and $Z$ in this city.

\section{METHODOLOGY}

This study is qualitative research using a qualitative descriptive design approach. The purpose of descriptive research is to make a systematic, factual, and accurate description, picture, or painting of the facts, properties, and relationships between the phenomena investigated. This study aims to obtain primary data from several informants represented by Gen X, Y, and Z, to obtain precise and accurate data to be utilized in this study. The data analysis technique in this research uses a case study that is one of the strategies and methods of qualitative data analysis that emphasizes specific cases on the analysis object. In this research, the type of case study used is an observational case study, which, according to Bogdan and Biklen (1982) in Bungin (2011), emphasizes more on the use of observations in research to capture detailed and actual empirical information from the research analysis unit, whether this concerns the lives of individuals and specific social units in society in Indonesia.

This study's object was several generations of X, Y, and Z selected to become informants in this study. In determining informants in this study, researchers used the snowball method (snowball), also known as the referral chain procedure or networking procedure. In this procedure, with whom participants or informants have been contacted or first met with researchers, it is essential to use their social networks to refer researchers to other people who have the potential to participate or contribute and learn or provide information to researchers (Bungin, 2011). Informants involved in this study were 30 people, ten from Gen X, ten from Gen Y, and ten from Gen Z. Specifically for Gen X, the informants consisted of practitioners, academics, and the general public. The informants from Gen X and Gen $Z$ are also equipped with different educational and professional backgrounds. By way of the exponential discriminative snowball model, the researcher tried to get the 30 informants interviewed to produce good research about increasing literacy.

Data collection was done by focus group discussion (FGD) conducted with three groups in genes $X$ Y and $Z$ to determine each gene's level of understanding. Observations were also made with in-depth observations and systematic recording of the symptoms and data relating to increasing financial literacy through sharia fintech for Gen X, Y, and Z. Furthermore, In-depth interviewing 
was carried out by interviewing all the informants mentioned earlier. Interviews are unmanaged (unstructured) and guided (structured) (Soeratno, 1995 and Usman \& Akbar, 1996). Interviews were conducted offline and online. Finally, documentation is done by documenting all matters relating to the research object, whether in personal documents or official documents (Bungin, 2011). The researchers employed triangulation methods, theories, and data sources to validate the research results.

This research was conducted by digging field data from 30 informants, which were divided into three age groups, namely Gen X, Gen Y, and Gen Z. The informants in Gen $X$ and $Y$ were mostly filled with practitioners and academics. The informants in Gen $Z$ are dominated by university students, especially those who study in the Sharia Economics Study Program and Islamic Banking. Informants are limited to those who understand or use sharia fintech. Therefore several informants who did not fit this criterion were eliminated by the researcher. Researchers entered several discussion forums, seminars, and Focus Group Discussion (FGD) related to fintech topics and topics. Due to limited research funding, researchers do not hold FGDs intensively, but researchers have attended FGDs related to sharia fintech and digging data in the forum, according to the research topic being carried out by researchers. For more details, refer to informants in this study through the following table:

Table. 1. List of Informants in Research

\begin{tabular}{|c|c|c|c|}
\hline Gen & Variables studied & Informant (Initial) & Information \\
\hline \multirow[t]{3}{*}{$\begin{array}{l}X \\
\text { (Age } \\
40-60 \\
\text { years } \\
\text { old) }\end{array}$} & $\begin{array}{l}\text { Sharia Financial } \\
\text { Technology } \\
\text { Education and } \\
\text { Socialization }\end{array}$ & $\begin{array}{l}\text { (1) Mr. AKR (UINSA lecturer) } \\
\text { (2) Mrs. HS (Private company) } \\
\text { (3) Mr. SS (Private company) } \\
\text { (4) Mrs. VS (Catering Entrepreneur) }\end{array}$ & \multirow{3}{*}{$\begin{array}{l}\text { Interviews with all } \\
\text { informants were carried } \\
\text { out directly or } \\
\text { indirectly, online or } \\
\text { offline. Some } \\
\text { informants were met } \\
\text { through discussion } \\
\text { forums and FGDs about } \\
\text { Fintech in Zoom media } \\
\text { or at the FGD event } \\
\text { about Fintech at } \\
\text { Airlangga University, } \\
\text { Surabaya. }\end{array}$} \\
\hline & $\begin{array}{l}\text { Improvement of } \\
\text { Islamic Financial } \\
\text { Technology } \\
\text { Infrastructure }\end{array}$ & $\begin{array}{l}\text { (1) Mrs. ET (UNJ lecturer) } \\
\text { (2) Mrs. FF (UINSA lecturer) } \\
\text { (3) Mr. SS (UNAIR lecturer) }\end{array}$ & \\
\hline & $\begin{array}{l}\text { Development of } \\
\text { Financial Products } \\
\text { and Services of } \\
\text { Islamic Financial } \\
\text { Technology }\end{array}$ & $\begin{array}{l}\text { (1) Mr. MM (OJK Jawa Timur) } \\
\text { (2) Mr. E (PT. Fintech Karya } \\
\text { Nusantara) } \\
\text { (3) Mrs. AH (UNAIR lecturer) }\end{array}$ & \\
\hline \multirow[t]{3}{*}{$\begin{array}{l}\text { Y } \\
\text { (Age } \\
25-39 \\
\text { Years } \\
\text { old) }\end{array}$} & $\begin{array}{l}\text { Sharia Financial } \\
\text { Technology } \\
\text { Education and } \\
\text { Socialization }\end{array}$ & $\begin{array}{l}\text { (1) Mrs. RF (Teacher and } \\
\text { Entrepreneur) } \\
\text { (2) Mrs. RZK (Designer and } \\
\text { Entrepreneur) } \\
\text { (3) Mr. RR (A teacher of Islamic } \\
\text { school) } \\
\text { (4) Mrs. WW (Private employee) }\end{array}$ & \multirow{3}{*}{$\begin{array}{l}\text { Interviews with all } \\
\text { informants were carried } \\
\text { out directly or } \\
\text { indirectly, online and } \\
\text { offline. Some informants } \\
\text { were met through } \\
\text { discussion forums and } \\
\text { FGDs about Fintech in } \\
\text { Zoom media or at the } \\
\text { FGD event about } \\
\text { Fintech at Airlangga } \\
\text { University, Surabaya. }\end{array}$} \\
\hline & $\begin{array}{l}\text { Infrastructure } \\
\text { Improvement of } \\
\text { Islamic Financial } \\
\text { Technology }\end{array}$ & $\begin{array}{l}\text { (1) Bapak SB (DSN-BI) } \\
\text { (2) Bapak AN (Dosen UMS) } \\
\text { (3) Bapak RR (Dosen UINSA) }\end{array}$ & \\
\hline & $\begin{array}{l}\text { Development of } \\
\text { Financial Products } \\
\text { and Services of }\end{array}$ & $\begin{array}{l}\text { (1) Mr. HW (UIKA lecturer and } \\
\text { practitioner) }\end{array}$ & \\
\hline
\end{tabular}




\begin{tabular}{|c|c|c|c|}
\hline Gen & Variables studied & Informant (Initial) & Information \\
\hline & $\begin{array}{l}\text { Islamic Financial } \\
\text { Technology }\end{array}$ & $\begin{array}{l}\text { (2) Mr. MY } \text { (Sharia Banking } \\
\text { Practitioner) } \\
\text { (3) Mr. IS (Practitioner and } \\
\text { Motivator) }\end{array}$ & \\
\hline \multirow[t]{3}{*}{$\begin{array}{l}\text { Z } \\
\text { (Age } \\
\text { 10-24 } \\
\text { years } \\
\text { old) }\end{array}$} & $\begin{array}{l}\text { Sharia Financial } \\
\text { Technology } \\
\text { Education and } \\
\text { Socialization }\end{array}$ & $\begin{array}{l}\text { (1) NN (Undergraduate student) } \\
\text { (2) NW (Undergraduate student) } \\
\text { (3) WK (Undergraduate student) } \\
\text { (4) SS (Undergraduate student) }\end{array}$ & \multirow{3}{*}{$\begin{array}{l}\text { Interviews with all } \\
\text { informants were carried } \\
\text { out directly or } \\
\text { indirectly, online and } \\
\text { offline. The informants' } \\
\text { selection was performed } \\
\text { after the snowball } \\
\text { process and only } \\
\text { involved informants } \\
\text { who understood or } \\
\text { utilized sharia fintech. }\end{array}$} \\
\hline & $\begin{array}{l}\text { Improvement of } \\
\text { Islamic Financial } \\
\text { Technology } \\
\text { Infrastructure }\end{array}$ & $\begin{array}{l}\text { (1) US (Postgraduate student) } \\
\text { (2) TS (Postgraduate student) } \\
\text { (3) NST (Postgraduate student) }\end{array}$ & \\
\hline & $\begin{array}{l}\text { Development of } \\
\text { Fintech Sharia } \\
\text { Financial Products } \\
\text { and Services }\end{array}$ & $\begin{array}{l}\text { (1) DD (Postgraduate student) } \\
\text { (2) ERD (Postgraduate student) } \\
\text { (3) LH (Postgraduate student) }\end{array}$ & \\
\hline
\end{tabular}

Source: Processed data

The table above explains some of the informants in this study. First, informants in the Gen X group were obtained from FGD forums, seminars, and researchers' discussions. For example, the FGD was attended by researchers at Airlangga University, which involved the Heads of Sharia Banking Branches, OJK Central and East Java, the Indonesian National Sharia Board, and owners of Sharia Fintech. The FGD was conducted by Airlangga University Lecturers, who researched sharia fintech. Researchers attended the FGD as Representatives of the East Java Sharia Economic Community Management; secondly, informants in the Gen Y group were also discovered by researchers from intensive discussions with practitioners and academics from sharia fintech. In-depth interviews were conducted online with zoom media and Whatsapp video calls. The majority of informants in the Gen Z group were students at STIE Perbanas Surabaya and UIN Sunan Ampel Surabaya.

\section{RESULT AND DISCUSSION}

\section{Results}

\section{Education and Socialization of Fintech Sharia Perspective for Gen X, Y, and Z}

OJK has issued OJK Regulation No. 13 / POJK.02 / 2018 regarding Digital Financial Innovation in the Service and Financial Sector as a provision that oversees the financial technology industry's supervision and regulation (Fintech). OJK has also previously issued OJK Regulation No 77 / POJK.01 / 2016 concerning Technology-Based Lending and Borrowing Services. Suharyati \& Sofyan (2018) quoted Wimboh Santoso as saying that the regulations issued by the OJK were issued due to the rapid advancement of industrial technology in the digital financial industry. This condition needs to be managed well in order to provide significant benefits for the community. Therefore, digital financial innovation can be upgraded to responsible, secure service and promotes consumer protection because risks can be managed very well. 
Socialization is an environmental examination of a social culture from the community. This action includes some interactions and social behavior, which is how to introduce a system to someone. Socialization is determined by the social, economic, and cultural environment, which is determined by the interaction of each individual's experiences. Buhler (1980) explained that socialization is a process that helps community members to learn and adapt, related to how they live and think so that he can play a role and function in the group. According to the Big Indonesian Dictionary, the understanding of education changes people's attitudes and behavior to mature themselves through teaching, training, processes, and ways of educating.

The socialization of increasing sharia financial literacy on sharia fintech is related to society's existing social culture. The system is then introduced and strengthened by the social, economic, and cultural environment and adjustment efforts. According to AKR, a lecturer, the socialization for Islamic Fintech does not exist, and the public does not know even the existence of Islamic Fintech. He stated:

"Fintech Sharia does not seem to exist. A payment gateway is not available, even though it is needed. I am a lecturer at an Islamic-affiliated university; in my opinion, Sharia payment gateways should exist to safeguard Muslim consumers' rights."

Several other informants also approved the statement regarding the need for a sharia-based payment gateway. According to HS, a private employee, if conventional payment gateways are still based on usury, then Muslim consumers do not have the option to use financial facility services such as payment gateways to facilitate daily financial activities. He even added:

"If sharia-based financial services for payment gateways are not available, then one relies on Ustadz's opinion. Consumers do not make sin when using a conventional payment gateway, even if based on usury. When there is sin, it is the responsibility of the government."

Regarding peer-to-peer lending products at Sharia fintech, all informants disagree with sharia peer-to-peer. For them, peer-to-peer lending at Sharia fintech is not much different from conventional peer-to-peer lending. For most informants, if a Sharia fintech propagates itself as sharia, it should not take high profits from borrowing customers. SS stated:

"Conventional Fintech fooled my friend, and the Fintech was very cruel. I am not very familiar with Sharia fintech. However, from the information that I got, fintech Sharia also takes very high profits from customers. This is no different from the interest of conventional banks, even higher than conventional banks. In the end, I was disappointed in many Sharia products, including Fintech. "

AKR stated the statement about sharia peer-to-peer lending, he explained:

"There are several schools of thought regarding bank interest. One states that if at the point where the borrower is not burdensome, the bank interest is not usury. If you see Sharia fintech, then there is an element of wrongdoing 
because the profit for Fintech is high and the borrower feels objected, then this removes the essence of sharia. "

Social culture in the community explains that peer-to-peer lending products in Islamic Fintech are not well understood. Even Gen X, in this study, did not understand the existence of sharia peer-to-peer lending. They only assume that the presence of Sharia peer-to-peer lending attracts high profits from customers, thus stating that the Sharia peer-to-peer lending is the same as conventional peerto-peer lending.

In terms of Islamic crowdfunding, the informants welcomed the products. According to them, many parties felt the benefits of Islamic crowdfunding, primarily to distribute the charity that the community wanted to distribute. They hope that Sharia fintech actors who have Sharia crowdfunding can carry out their business reliably.

Education to improve sharia financial literacy, especially for fintech products, is carried out by changing attitudes and behaviors through testing, training, and process efforts. Some of the researchers' education to the four informants initially was to explain some of the products from Islamic Fintech. After several meetings, the researcher asked the informant again about payment gateway, peer-to-peer lending, and crowdfunding perspective of sharia literacy. AKR explained that the existence of sharia fintech is not essential to him; he explained:

"In my opinion, people's enthusiasm for conventional banks is normal. The same thing applies to the existence of Sharia fintech."

Changes in people's attitudes and behavior to be able to understand the existence of Islamic Fintech, according to the SS, must be driven by awareness of the needs of Islamic Fintech itself. He explained:

"Our society is now smart. When people need one financial service product, the product will be in demand, whether sharia or not. However, sometimes a product is wrapped in sharia, but it deceives people, giving up with the sharia product."

The four informants agreed that sharia crowdfunding could be well developed, especially for product distribution and noble programs. They can be developed to alleviate poverty, which can strengthen the Indonesian economy.

\section{Sharia Fintech Infrastructure Improvement from Gen X, Y and Z Perspectives}

Fintech is one solution for overcoming financial problems in the community, especially those far from banking access or non-bankable communities (Rumondang, 2018). The survey conducted by the Indonesian Fintech Association (AFTECH) explained that more than $70 \%$ of the fintech startup focus provided services in segments not served by banks (Suryanto, Tahir, Hermanto, 2020).

Regarding infrastructure improvements in Islamic Fintech, several informants stated that Islamic Fintech is still very limited. Therefore, efforts to improve infrastructure in Islamic Fintech are the task of many parties. SS stated:

"There are many technological gaps that make Islamic fintech lag behind conventional Fintech. Many Islamic banks cannot issue payment gateways." 
SB also stated that the underdevelopment of infrastructure in Islamic Fintech ultimately inhibited the development of Islamic Fintech. This condition mostly happens when it comes to the relationship between Islamic Fintech and venture capital. SB stated:

"While there are only two sharia fintechs that get financing from venture capital, the main reason is that sharia fintech has not been supported by good infrastructure."

The existence of infrastructure in sharia fintech significantly affects the fintech market ecosystem, with future demand being Muslim communities. Indonesia, with the largest Muslim population in the world, is an opportunity that should be utilized by Islamic Fintech to develop. Therefore, infrastructure improvement in various sectors that support the acceleration of Islamic Fintech should be performed well.

\section{Sharia Financial Products and Services Development from Gen X, Y and Z Perspectives}

The development of Islamic financial products and services in Islamic Fintech dramatically influences the development of Islamic Fintech itself. MM explained that many MSME players utilized sharia fintech niches because the access was felt more comfortable. He explained:

"Many business players, especially MSMEs, use sharia fintech. Many MSMEs also hope that fintech sharia is predicted to provide sharia-based capital solutions with quick and easy access. "

Furthermore, there are outstanding opportunities to develop Islamic fintech products and services by cooperating with several institutions and other parties. E stated that the government provided good support for the development of Islamic Fintech:

"The vice president supports the excellent cooperation between fintech sharia with micro-financing of Islamic banks and Islamic banks. By utilizing digital technology, Islamic finance products and services will be accessible to the broader community, using the Islamic fintech form. "

Efforts to develop products and services on Islamic Fintech will not be able to run correctly without government intervention, Islamic fintech association (AFSI), SMEs, capital providers, and from DSN-MUI that can facilitate the rules of conducting transactions Islamic finance based on Islamic Fintech.

\section{CONCLUSIONS}

This research concludes that there are still many obstacles in developing Islamic Fintech, especially in the acceleration, there is a sharia-based payment gateway. Peer-to-peer lending based on fintech sharia has been relatively developing, although it is still significantly behind at the infrastructure level compared to conventional Fintech. The research finally finds that there is an unfortunate fact that $\mathrm{Z}$ generations are not in favor of sharia fintech in the area of payment gateway, peer to peer lending, and crowdfunding. The socialization and education of Islamic Fintech are significant for Islamic Fintech, significantly 
increasing the fintech-based Islamic financial inclusion. Many have not felt the public still awaits the presence of Islamic Fintech. In Islamic crowdfunding, online reporting-based accountability must be actively carried out and promoted to boost popularity and gain public trust. According to gen $X$, sharia fintech must be disseminated among the Muslim communities so that peer-to-peer lending sharia can easily be accessed. Concerning the sharia fintech infrastructure, the $Y$ generations think there is a gap between sharia fintech and conventional Fintech. In the meantime, $x$ and $Z$ generations assume that the strengthening of the financial literacy as far as the product and services of sharia finances are concerned may have an excellent contribution to the empowerment of the smallmedium enterprises.

\section{REFERENCES}

Abdullah, M. A., \& Chong, R. (2014). Financial literacy: An exploratory review of the literature and future research. Journal of Emerging Economies and Islamic Research, 2(3), 1-9.

Agustinus, M. (2019). RI juga Butuh Infrastruktur Keuangan Bukan Hanya Infratruktur Fisik. Dalam finance.detik.com diakses 20 Juni 2020 pukul 19.00 .

Budiman, A. (2019) Kolom Pakar: Industri 4.0 VS Society 5.0 dalam Fakultas Tehnik Universitas Gadjah Mada, di ft.ugm.ac.id (diakses 27/09/2019, pukul 09.15).

Bungin, B. (2007). Penelitian kualitatif: komunikasi, ekonomi, kebijakan publik, dan ilmu sosial lainnya (Vol. 2). Kencana.

Buhler, C. (1980). Practice Kinder Psychology. Boston: Houghton Mifflin, Co.

Direktorat Jenderal Aplikasi Informatika, Kemetrian Komunikasi dan Informatika. (2018). Big Data, Kecerdasan Buatan, Blockchain dan Teknologi Finansial di Indonesia: Usulan Desain, Prinsip dan Rekomendasi Kebijakan. Jakarta: Centre for Innovation Policy and Governance (CIPG).

Fianto, B. A., Hendratmi, A., \& Aziz, P. F. (2020). Factors determining behavioral intentions to use Islamic financial technology. Journal of Islamic Marketing. Ahead-of-print. Accessed from https://doi.org/10.1108/JIMA-12-2019$\underline{0252}(25 / 09 / 2020)$.

Er, B., \& Mutlu, M. (2017). Financial inclusion and Islamic finance: A survey of Islamic financial literacy index. International Journal of Islamic Economics and Finance Studies, 30(5661), 33-54.

Fauzia, I. Y. (2019). Pemanfaatan Jaringan Internet dalam Transaksi Perspektif Bisnis Islam. Jakarta: PT. Raja Grafindo Persada.

Firmansyah, H. B., \& Ramdani, A. L. (2018). The role of Islamic financial technology (FinTech) startup in improving financial inclusion in Indonesia case: In the 3rd International Conference of Integrated Intellectual Community (ICONIC). Available at SSRN: https:// ssrn.com/abstract=3194546 or http://dx.doi.org/10.2139 Lssrn.3194546

Jepang. (, 2019). Realizing Society 5.0 (Powered by News Pick Brand design) dalam japan.go.jp (diakses 01/10/2019). 
Kominfo. (2019). Pemerintah Petakan 6 Fokus Inklusi Keuangan Indonesia Tahun 2019. Dalam kominfo.go.id (diakses 27/10/2019, pukul 21.30)

Kementrian Pendidikan dan Kebudayaan. (2017). Materi Pendukung Literasi Digital: Gerakan Literasi Nasional, Jakarta.

Mannheim, K. (1952). The Problem of Generations in Essays on the Sociological Knowledge. Essays on the Sociology of Knowledge, 24(19), 276.

Otoritas Jasa Keuangan. (2017). Strategi Nasional Literasi Keuangan Indonesia. Dalam ojk.go.id

Peraturan Bank Indonesia Nomor 19/12/PBI/2017 tentang Penyelenggaraan Teknologi Finansial dapat menyelenggarakan aktifitas keuangan.

Putra, Y. S. (2017). Theoritical review: Teori perbedaan generasi. Among Makarti, 9(18), 123-134.

Patria, R. (2020). Tantangan Fintech Sharia di Indonesia. Dalam domainesia.com diakses 20 Juni 2020, pukul 18.22.

PT. Telkom Indonesia. (2017). Kajian Bisnis Fintech Sharia. Bandung.

Puslitbang Kebijakan dan Penerapan Teknologi. (2019). Fintech: Alternatif Pembiayaan untuk Mendorong Pengembangan Ekonomi Wilayah. Dalam http://litbang.pu.go.id/, diakses 20 Juni 2020, pukul 21.00.

Prasad, H., \& Devendra, M. (2017). Digital Literacy: A Study of Households of Udaipur. Global Journal of Advanced Research. Vol. 4, Issue 5, PP. 201-2019. ISSN: 2394-5788 201. Accessed www.gjar.org. (30/09/2020).

Romānova, I., \& Kudinska, M. (2016). Banking and Fintech: a challenge or opportunity?. Contemporary issues in finance: Current challenges from across Europe. Emerald Group Publishing Limited.

Rumondang, A. (2018, April). The Utilization of Fintech (P2P Landing) as SME's Capital Solution in Indonesia: Perspective in Islamic Economics (Qirad). In International Conference of Moslem Society (Vol. 2, pp. 12-22).

Rusydiana, A. S. (2018). Developing Islamic financial technology in Indonesia. Hasanuddin Economics and Business Review, 2(2), 143-152.

Ryandono, M. N. H. (2018). Fintech Waqaf: solusi permodalan perusahaan startup wirausaha muda. Jurnal Studi Pemuda, 7(2), 111-121.

Siregar, (2016). "Financial Technology Tren Bisnis Keuangan ke Depan”. Diakses pada 1 April 2018 di (http://infobanknews.com) diakses 22 Oktober 2019 pukul 14.55 .

Suharyati, S., \& Sofyan, P. (2019). Edukasi Fintech Bagi Masyarakat Desa Bojong Sempu Bogor. Jurnal Bakti Masyarakat Indonesia, 1(2).

Hermanto, B., \& Tahir, R. (2020). Edukasi Fintech Bagi Pelaku Usaha Mikro, Kecil dan Menengah. Kumawula: Jurnal Pengabdian Kepada Masyarakat, 3(1), 1828.

Setyowati, A., Harmadi, H., \& Sunarjanto, S. (2018). Islamic financial literacy and personal financial planning: a socio-demographic study. Jurnal Keuangan dan Perbankan, 22(1), 63-72.

Setyaningsih, E. D. (2018). Analisis SWOT Implementasi Financial Technology Syariah pada PT Telkom Indonesia. Syiar Iqtishadi: Journal of Islamic Economics, Finance and Banking, 2(2), 73-91. 
Tony, N., \& Kavitha D. (2020). Impact of Digital Financial Literacy on Digital Financial Inclusion, International Journal of Scientific \& Technology Research, Vol. 9: (1). ISSN. 2277-8616 1911. Accessed from http://www.ijstr.org/final-print/jan2020/Impact-Of-Digital-FinancialLiteracy-On-Digital-Financial-Inclusion.pdf (25/09/2020).

Sources from internet:

https://www.indopremier.com/, diakses 02/12/2019.

https://www.beritasatu.com/, diakses 04/12/2019.

http://kanal24.co.id/ diakses 02/12/2019. 